\title{
Business Administration And Computer Science Degrees: Earnings, Job Security, And Job Satisfaction
}

Dr. Kamlesh Mehta, National University, Chair, Department of Management and Marketing, USA

Dr. Ronald Uhlig, National University, USA

\begin{abstract}
This paper examines the potential of business administration vs. computer science degrees in terms of earnings, job security, and job satisfaction. The paper focuses on earnings potential five years and ten years after the completion of business administration and computer science degrees. Moreover, the paper presents the income changes with promotion and lifetime earnings expectations of both the business administration and computer science graduates.
\end{abstract}

Keywords: Business Administration; Computer Science; Earnings; Job Security; Job Satisfaction

\section{INTRODUCTION}

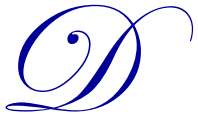

ebate in the United States has raged over whether the cost of a college education is worth the benefit, regardless of the type of degree. The Education Report (US Bureau of Labor Statistics, 2013a) examines the value of college in both financial and nonfinancial terms. Both the business administration and computer science degrees lead to potential for higher earnings. According to Pew Research Center (2011), "those who graduated from college estimated they were earning greater than $\$ 20,000$ more a year than they would without a degree, a figure that lines up with the census results".

Greenstone and Looney (2011) report that a " $\$ 102,000$ investment in a four-year college yields a rate of return of 15.2 percent per year - more than double the average return over the last 60 years experienced in the stock market (6.8 percent), and more than five times the return to investments in corporate bonds ( 2.9 percent), gold ( 2.3 percent), long term government bonds ( 2.2 percent), or housing $(0.4$ percent).” This is an average across all college degrees.

To better understand the issue of number of people choosing to select a business administration, computer science, or any other degree, this paper starts with what reasons people typically consider for choosing an occupation. The reasons typically include earnings (money and benefits), job security and job satisfaction. The following three subsections explore these reasons in the contexts of a computer science career and a business administration career.

\section{Earnings (Money and Benefits)}

The Forbes magazine noted that the five-year out salaries for MBA graduates averaged $\$ 159,000$ in 2013 (Badenhausen, 2013). Once the compensation packages are added, generally, the average earnings of MBA graduates tend to be higher than most other graduates.

The 2015-2016 PayScale College Salary Report (PayScale, 2016) reports a median salary of $\$ 72,900$ for an individual with 10 years or more of work experience after receiving a bachelor's degree in business administration, and $\$ 95,100$ for an individual with a master's degree, but they show mid-career median salaries as high as $\$ 148,000$ for individuals with an MBA.

Another source notes that "it is difficult to know what to expect from a business administration salary, as the discipline opens up many possible career paths, each with varying levels of supply and demand (Allbusinessschools, 
2016). The same source goes on to list median annual salaries for business administration graduates ranging from $\$ 48,560$ in Food Service Management to $\$ 123,450$ in Marketing Management.

In May 2013 the US Bureau of Labor Statistics (2013b) reported an average annual salary for computer positions of $\$ 81,860$ for computer occupations. This is an average across all of the various areas in which a computer scientist can specialize. A number of specializations have average annual salaries greater than $\$ 100,000$. For example, Software Developer, Systems Software specialists earn an average salary of \$104,480; Computer and Information Research Scientists earn an average salary of $\$ 109,260$ ((US Bureau of Labor Statistics, 2013b).

The 2015-2016 PayScale College Salary Report (PayScale, 2016) reports a median salary of $\$ 105,000$ for an individual with 10 years or more of work experience after receiving a bachelor's degree in computer science, and $\$ 121,000$ for an individual with a master's degree in computer science, and $\$ 128,000$ for an individual with both an MBA and a major in computer science.

Snyder reports median annual salaries of $\$ 112,000$ for individuals with bachelor's degrees in computer science and $\$ 129,500$ for individuals with master's degrees in computer science (Snyder, 2014). Another interesting fact noted in this article is that the median annual salary for individuals with both a computer science degree and a MBA is $\$ 149,400$.

All of these salaries are significantly more than the average annual salary of $\$ 46,900$ earned by young adults between 25 and 34 years old with any bachelor's degree, or $\$ 59,600$ with any master's degree or higher (USDE, 2014; NCES 2014).

\section{Job Security}

In a recent article, Sheri London (2014) reported that a recent Gallup poll showed that 58\% of all full-time or parttime workers say they feel completely satisfied with their level of job security. This is a significant improvement from the Great Recession, when the level of job security was only around $50 \%$. She further commented that the increase in confidence accompanied a decline in unemployment to $6 \%$ overall in 2014 . Unemployment continued to drop during 2015, reaching a low of 4.9\% in January 2016 (Schwartz, 2016).

College degrees in general confer much better job security, particularly during hard times. Near the end of the Great Recession, Jay Fitzgerald (2012) noted that, "College graduates are ... more likely to stay employed. In 2011, the unemployment rate nationally for those with at least a bachelor's degree was $5.3 \%$, well below the overall US rate of 9.1\%. Unemployment among those with just a high school diploma was $12.5 \%$. The jobless rate for high school dropouts was nearly 19\%." (Fitzgerald, Jay, 2012). In the same article, he noted that in those same tough times, graduates may not get a job in the field in which they earned their degree, but they will generally get employment before those without a degree.

Lindsay Olson (2013) commented that, "Business degrees have long been considered among the most utilitarian, simply because they can be applied to so many jobs. If you're wrapping up your Bachelor of Science in business or management, or if you're completing an MBA program, you've been exposed to numerous areas of business, including marketing, finance, statistics, and economics. You're an employer's dream come true" (Olson, 2013).

Another consideration for students considering what major to pursue is how likely they are to get a job offer when they graduate. Based on data gathered by the National Association for Colleges and Employers (NACE) in a survey of almost 10,000 university students in their final year, Susan Adams (2014) noted that $68.7 \%$ of Computer Science students had at least one job offer by the time they graduated, while $54.3 \%$ of Business Administration majors had at least one job offer.

The most recent data from NACE indicates that "business graduates are most in demand among employers recruiting bachelor's degree graduates from the college Class of 2016" (Gray and Koncz,2015). They go on to state that, "Nearly $70 \%$ of responding employers plan on hiring graduates from the business disciplines, while $66.7 \%$ anticipate hiring those in engineering and $57.8 \%$ expect to hire computer and information sciences graduates." It 
should be emphasized that these percentages are the percentage of responding companies that plan to hire - which is different from the percentage of graduates that received job offers, discussed in the preceding paragraph. The figure of $70 \%$ covers all business majors - not just business administration. The percentage of companies planning to hire computer science graduates $-53.9 \%$, was slightly higher than the $47.8 \%$ of companies planning to hire Business Administration/Management graduates.

Another indicator of job security is whether the demand for skilled workers in a particular field is increasing and by how much. The demand is increasing both for graduates with business administration skills and with computer science skills. The United States Bureau of Labor Statistics maintains the Occupational Outlook Handbook with more than 500 career fields listed. The handbook notes, "Employment of computer and information technology occupations is projected to grow 12 percent from 2014 to 2024 , faster than the average for all occupations. These occupations are expected to add about 488,500 new jobs, from about 3.9 million jobs to about 4.4 million jobs from 2014 to 2024 (BLSOOH, 2016).

The United States Bureau of Labor Statistics Occupational Outlook Handbook comments that, "Employment of business and financial operations occupations is projected to grow 8 percent from 2014 to 2024, about as fast as the average for all occupations, adding about 632,400 new jobs. In the job outlook for management analysts, the handbook projects an increase of 14\% during the 2014-2024.

The demand for individuals with computer science degrees is more than the numbers of people who are graduating with computer science degrees. The most recent data published showed a total of 15,975 bachelor's degrees in Computer Science awarded in 2012 and 7,462 master's degrees awarded, for a total of 23,437 (CRA, 2012).

Immedia Edu (2013) states that, "According [to] the Conference Board, in October 2013 there were 570,000 computing job openings in the United States, making these jobs the highest demand in the US -- about 4 times more than the US average" (Immedia Edu, 2013). "The US Bureau of Labor and Statistics noted that Mobile Application Development has the highest growth potential with 292,000 more jobs expected over the decade and in the area of Video Game Design, "over the next 10 years, it predicts 30 percent job growth, with 270,900 new positions being added" (Willmott, 2013). The huge shortfall between the number of computer science graduates and the demand for these skills suggests a high level of job security.

\section{Job Satisfaction}

In their introduction to the 100 Best Jobs of 2015, the staff of US News recently discussed job satisfaction as follows: "The U.S. workforce has myriad talents, desires and lifestyles, so there is no one best job that suits each one of us. But if we were to define a good job generally, there are some unequivocal factors. The best jobs pay well. They challenge you without stressing you out too much. There's room to grow and advance. Maybe most importantly, the best jobs are ones that are hiring" (US News and World Report, 2015). They go on to list three computer science categories among the Top Ten in their list of the 100 best jobs: Software developer \#3, Computer Systems Analyst \#7, and Information Security Analyst \#8.

The most recent results from StudentsReview ${ }^{\mathrm{TM}}$ (2015) show that $72.1 \%$ of all business - management administration degree graduates are satisfied with their jobs, and $78.2 \%$ feel that things are generally going well for them in their jobs. Neither Business - Management Administration nor Computer Science have the highest StudentsReview ${ }^{\mathrm{TM}}$ job satisfaction ranking. Computer Science job satisfaction has a ranking of $67.7 \%$, which is above the $60.5 \% \%$ job satisfaction ranking averaged across all majors. Computer Science also does better than the average across all majors in the "going well" category, with a ranking of $74.8 \%$ versus an average ranking of $66.8 \%$ across all majors.

It is interesting to note that the StudentsReview ${ }^{\mathrm{TM}}$ (2015) student satisfaction survey data does not completely agree with results of the Gallup/Purdue University survey. Satisfaction with business - management administration job satisfaction is higher than computer science, and physics (71.2\%) but lower than other majors.

Some other indicators related to job satisfaction are also available in the StudentsReview ${ }^{\mathrm{TM}}$ (2015) survey results. They show an unemployment rate of $4.2 \%$ and decreasing for computer science graduates. This is not the lowest 
unemployment rate, but it is among the lowest and is significantly better than the average unemployment rate of $6.84 \%$ across all majors. By comparison, the unemployment rate for business - management administration at $8.1 \%$ is nearly double the unemployment rate for computer science.

A third measure related to job satisfaction is the percentage of graduates who are still in their field. They note that "students leave their 'field/major' for a number of reasons -- usually insufficient salary, job satisfaction, or employment rates." $68.9 \%$ of Business - Management Administration graduates are still in their field. "Insufficient salary" and "employment rates" can both be eliminated for computer science, leaving job satisfaction as the key indicator for this major. With $79.0 \%$ "still in the field", computer science ranks third highest in a list of 75 majors surveyed (StudentsReview ${ }^{\mathrm{TM}}, 2015$ ).

Students also report high satisfaction with their learning experience. In her blog, Stanford computer science student Vinamrata Singal commented, "My problem solving skills have become immensely better after becoming a computer science major" (Singal, 2013).

\section{METHODOLOGY}

The data used in this research study were based on surveys of business administration and computer science graduates of National University. Two independent surveys of a sample of graduates of National University were conducted to gain some insight into how their jobs and their compensation changed after receiving their degrees.

The first survey was directed at graduates of the National University MBA and BBA programs and was initiated in February 2013. The more than 15,000 students who graduated from these two program during the previous 41 years were queried. 463 graduates responded, which represents a response rate of just under 3\%. The data were divided into two categories: recent graduates and older graduates. Recent graduates were defined as those who had received their degrees since 1997, while older graduates were defined as those who completed their degrees during or before 1997. Sixty percent of the responses came from the recent graduates, while forty percent of the responses came from older graduates.

A survey asking an identical set of questions of computer science graduates was conducted in November and December 2014. The survey was sent to 1,367 graduates who received a Bachelor's and/or Master's degree in Computer Science from National University since the BS degree began in 1982. A response rate of 10.9\% (149 graduates) was received. Ninety-one percent of the responses came from recipients of Bachelor of Science in Computer Science degrees, while $9.4 \%$ of the responses came from graduates who had received Master of Science in Computer Science degrees. Thirty-nine percent of the responses came from graduates who had received their degree during the past 15 years, i.e. since 1999. Sixty percent of the responses came from graduates who received their degree before 1999 .

The results of the business administration graduates have been published (Uhlig, Mehta, Silverstone, and MossavarRahmani, 2015). The results of the computer science graduates have also been published (Uhlig and Mehta, 2016). In this paper, based on the results of the earlier surveys, the authors present a comparative analysis of the earnings potential between the business administration and computer science graduates.

\section{THE RESULTS - A COMPARISION}

Based on the results of the earlier surveys published by the authors (Uhlig, Mehta, Silverstone, and MossavarRahmani, 2015; Uhlig and Mehta, 2016), a comparative analysis of the earnings potential between the business administration and computer science graduates is presented next.

Unlike traditional universities with baccalaureate students in the 18-25 year-old age group, National University focuses on higher education for working adults. Most National University students are working adults. All baccalaureate students have a high school degree. Graduate students have at least a Bachelor's degree. Some already have another Master's degree. There are more than 3500 alumni with Bachelor of Science and Master of Science degrees in computer science and over 16000 alumni with Bachelors and Master degrees in business 
administration. National University students have an average age in the mid-thirties, and they often have five to ten years of work experience before beginning their studies.

All three of the factors "money and benefits", "job security" and "job satisfaction" are important, but this paper focuses on earnings and employability of National University's business administration and computer science graduates.

We were particularly interested to learn whether increases in salary corresponded with receipt of degrees. Some employees may already be compensated at the maximum of the range for their current position. The position description may not even require a college degree. An employer may not consider receipt of a new degree sufficient reason to increase the salary of an employee who is doing satisfactory work. The new graduate may have to change jobs to be able to receive a higher salary. This may require changing positions within their current organization or even changing employers. The averages and medians reported in this paper are only general indicators about these kinds of changes. It should be noted that the experiences of individuals may vary significantly from these averages and medians.

Tables 1 and 2 compare income increases after five and ten years for computer science graduates and business administration graduates. Looking first at Table 1 comparing income increases five years after graduation, $8 \%$ more computer science graduates than business administration graduates reported increases of less than $20 \%$. In the combined $20 \%-40 \%$ increase category, $17 \%$ more business administration graduates than computer science graduates reported increases. However, $36 \%$ of computer science graduates reported income increases of $40 \%$ or more, compared with $28 \%$ of the business administration graduates. There is a considerably smaller percentage of computer science graduates with income increases in the $20-40 \%$ range. The distribution of income increases is considerably different for the computer science graduates than for the business administration graduates, tending to peak in the middle for business administration graduates, but having a trough in the middle for the computer science graduates.

Table 1. Comparison of Increases in Incomes Five Years After Degree Completion

\begin{tabular}{l|cc}
\hline \multicolumn{1}{|c}{ Percentage Increase } & Business Administration & Computer Science \\
\hline Less than $20 \%$ & $\mathrm{~N}=248$ & $28 \%$ \\
\hline $20-30 \%$ & $20 \%$ & $20 \%$ \\
\hline $31-40 \%$ & $32 \%$ & 144 \\
\hline $41-50 \%$ & $20 \%$ & $12 \%$ \\
\hline More than $50 \%$ & $8 \%$ & $24 \%$ \\
\hline Total & $19 \%$ & $100 \%$ \\
\hline
\end{tabular}

Table 2 shows similar distributions of income increases after ten years for business administration graduates and computer science graduates, with a peak in the $31 \%-50 \%$ income increase category for business administration and with business administration ahead of computer science by $11 \%$ in this category. Both the five year and ten year figures indicate a larger percentage of computer science graduates remaining at income increases of less than $20 \%$. Based on a number of survey comments about having worked in computer science for a number of years before getting their degree, it is conjectured that these people already had higher incomes because of their experience levels, but data are not available to prove or disprove this. Both the five year figures and ten year figures show larger increases for computer science graduates in the highest ranges of percentage increases. 
Table 2. Comparison of Increases in Incomes Ten Years After Degree Completion

\begin{tabular}{l|cc}
\hline \multicolumn{1}{c}{ Percentage Increase } & Business administration & Computer Science \\
\hline Less than $20 \%$ & $\mathrm{~N}=240$ & $21 \%$ \\
\hline $20-30 \%$ & $11 \%$ & $15 \%$ \\
\hline $31-50 \%$ & $15 \%$ & $19 \%$ \\
\hline $51-100 \%$ & $30 \%$ & $17 \%$ \\
\hline More than $100 \%$ & $22 \%$ & $28 \%$ \\
\hline Total & $22 \%$ & $100 \%$ \\
\hline
\end{tabular}

Table 3 compares income changes with promotion. Eleven percent more computer science graduates than business administration graduates reported increases of less than $10 \%$. In the combined $10 \%-30 \%$ increase range, $23 \%$ more business administration graduates than computer science graduates reported increases. There is a considerably lower percentage of computer science graduates with income increases in the $21-30 \%$ range. The increase in income with promotion in $31 \%-40 \%$ range was the same for both business administration and computer science graduates.

Table 4 compares lifetime expectations of earnings. It is important to note that this has considerable subjectivity, because a relatively small number of those surveyed have reached retirement age. There is a considerable difference in expectations between the two groups of graduates. While $62 \%$ of the business administration graduates expect to earn twice what they were earning before obtaining their degree, this number is only $45 \%$ for computer science graduates. The percentage of computer science graduates expecting to earn five times more and ten times more is considerably larger. The higher expectations of earnings for computer science graduates would appear to correspond to higher salaries for recent computer science graduates, but there are likely other factors involved as well. Moreover, it is worth noting that holding a business degree - particularly a MBA can be critical in obtaining the senior management positions that have the highest compensation levels.

Table 3. Income Changes With Promotion

\begin{tabular}{|c|c|c|}
\hline Answer & $\begin{array}{l}\text { Number of Responses } \\
\qquad \mathrm{N}=254\end{array}$ & $\begin{array}{c}\text { Percentage } \\
\mathrm{N}=141\end{array}$ \\
\hline Less than $10 \%$ & $24 \%$ & $35 \%$ \\
\hline $10-20 \%$ & $40 \%$ & $30 \%$ \\
\hline $21-30 \%$ & $29 \%$ & $16 \%$ \\
\hline $31-40 \%$ & $6 \%$ & $6 \%$ \\
\hline More than $40 \%$ & $11 \%$ & $13 \%$ \\
\hline Total & $100 \%$ & $100 \%$ \\
\hline
\end{tabular}

Table 4. Comparison of Lifelong Expectations of Earnings

\begin{tabular}{l|c|c}
\multicolumn{1}{c}{ Lifetime Earnings Expectation } & Business Administration & Computer Science \\
& $\mathrm{N}=421$ & 134 \\
\hline Earn twice what I was earning before obtaining my degree & $62 \%$ & $45 \%$ \\
\hline Earn five times more income as a result of my degree & $26 \%$ & $36 \%$ \\
\hline Earn ten times more income as a result of my degree & $7 \%$ & $13 \%$ \\
\hline Earn fifteen times more income as a result of my degree & $5 \%$ & $6 \%$ \\
\hline Total & $100 \%$ & $100 \%$ \\
\hline
\end{tabular}

\section{CONCLUSIONS}

Three criteria for choosing a degree in computer science were discussed: 1) earnings (money and benefits), 2) job security, and 3) job satisfaction. People with a degree, either in business administration or computer science, on average have high lifetime earnings (money and benefits), job security, and job satisfaction. 
In a survey of National University business administration graduates conducted in February- March 2013, 70\% of respondents stated that their annual income increased as a result of obtaining their degree; while $25 \%$ indicated no increase in income. In a similar survey of National University Computer Science graduates conducted in November-December 2014, 84\% responded that their annual income had increased as a result of obtaining their degree, while $14 \%$ indicated no increase in income.

The distribution of income increases five years after graduation and ten years after graduation was considerably different for business administration graduates and computer science graduates. The distribution for business administration graduates tends to peak in the range of $20-40 \%$ while the distribution for computer science graduates has a trough in this same range. The data would seem to indicate that for those computer science graduates who move up, they tend to move to higher salaries faster than their business administration counterparts. However, a slightly larger percentage of computer science graduates stay at smaller income increases.

More computer science students than business administration students changed companies to receive a higher position after receiving their degree. This may indicate that computer science students are more mobile as a result of obtaining their degree. Alternatively, it may be associated with the fact that some businesses are willing to subsidize the education of business administration students. The most likely scenario is a combination of these two factors.

The business administration, especially a MBA, may still be the best path to the high levels of compensation associated with the most senior positions in corporate management. However, computer science graduates surveyed had a higher expectation of increased lifetime earnings than their business administration counterparts.

Overall, the differences between the two groups of students surveyed may not be large enough to overcome following a path of least resistance in career choice. High levels of effort are required in pursuit of both the degrees. Fear concerning the level of effort required may be the deciding factor that prevents potential students from exploring the benefits associated with money, job security and job satisfaction when they are choosing a major. Individual drive and motivation will be the best determinants of success, whether in business administration, computer science, or any other field of study.

\section{AUTHOR BIOGRAPHIES}

Dr. Kamlesh Mehta is an internationally known professor, research scholar, administrator, and a consultant. Currently, Dr. Mehta is the Chair of the Department of Management and Marketing, Director of the MBA Program, and Professor of International Business and Marketing at National University in California and is on the Editorial Advisory Board of the Journal of Business Case Studies and the International Journal of Management and Information Systems. As a research scholar, the Harvard Business School Publisher has recognized Dr. Kamlesh Mehta in The International Directory of Business and Management Scholars and Research in the United States. In his decades of academia and global business experiences, Dr. Mehta has published over 50 scholarly research papers, eight of which have earned him outstanding research awards. Recently, he completed "The Art and Craft of Discussion Leadership", a certificate program from Harvard Business School, USA. E-mail: kmehta@nu.edu

Dr. Ronald P. Uhlig is a Professor in the School of Engineering and Computing, National University. He was Dean, School of Business and Management, 2010-2014. During 2005-2010 he served the School of Engineering and Technology in several positions including Chair, Department of Computer Science and Information Systems 20082010. Previous positions include President/CEO, SegWave, Inc., an educational technology startup he founded, and Vice President for Russia/Eastern Europe, Qualcomm Inc., He was with Northern Telecom and Bell-Northern Research 1978-1995. He is one of several "Fathers of email"; based on work he did with the US Army and DARPA in the 1970s and several international committees he chaired during 1979-91. He holds a B.Sc. in Physics from the Massachusetts Institute of Technology, and a Ph.D. in Physics from the University of Maryland. He is the recipient of a US Army Commendation Medal, and a Gold Medal from the International Telecommunications Academy for sustained contributions to telecommunications. E-mail: ruhlig@nu.edu 


\section{REFERENCES}

Adams, S., (2014). The College Degrees that Get the Most Job Offers, Forbes, January 22, 2014. Retrieved June 13, 2016, from http://www.forbes.com/sites/susanadams/2014/01/22/the-college-degrees-that-get-the-most-job-offers/\#327076307509

AllBusinessSchool.com (2016). Business Administration Salary and Job Outlook. Retrieved June 13, 2016 from http://www.allbusinessschools.com/business-careers/business-administration/salary/

Badenhausen K., (2013). Stanford Tops 2013 Rankings of List of American Business Schools, Forbes. Retrieved October 9 , 2013, from http://www.forbes.com/sites/kurtbadenhausen/2013/10/09/stanford-tops-2013-list-of-americas-bestbusiness-schools/

BLSOOH, (2016). Bureau of Labor Statistics Occupational Outlook Handbook www.bls.gov/ooh. Retrieved June 15, 2016, from http://www.bls.gov/ooh/computer-and-information-technology/computer-systems-analysts.htm and from http://www.bls.gov/ooh/business-and-financial/home.htm

CRA, (2012). Computing Degree and Enrollment Trends from the 2011-2012 CRA Taulbee Survey, Computing Research Association. Retrieved from http://cra.org/govaffairs/wpcontent/uploads/sites/6/2013/03/CRA_Taulbee_CS_Degrees_and_Enrollment_2011-12.pdf

Fitzgerald, J., (2012). College Degree is Costly, but It Pays Off Over Time, Boston Globe, Oct 7, 2012.

Greenstone, M. and Looney, A., (2011). "Where is the Best Place to Invest \$102,000 - In Stocks, Bonds or a College Degree", The Hamilton Project. Retrieved on January 29, 2015 from http://www.hamiltonproject.org/files/downloads_and_links/06_college_value.pdf

Gray, K. and Koncz, A., (2015). Employers Cite Desire to Hire Class of 2016 Business Graduates. Retrieved June 13, 2016, from http://www.naceweb.org/about-us/press/employers-desire-business-graduates.aspx

Immedia Edu, (2015). “1 $1 \mathrm{~mm}$ more jobs than students in computing, \$500B over 10 years.” Retrieved on March 8, 2015 from http://immediaedu.com/hour-of-code/computer-science-as-core/

London, S., (2014). More than Half of Americans Feel Satisfied with their Job Security, Retrieved June 13, 2016 from http://www.businessadministrationinformation.com/news/more-than-half-of-americans-feel-satisfied-with-their-jobsecurity

NCES, (2014). National Center for Education Statistics 2014, Fast Facts Report, Income of Young Adults. Retrieved from http://nces.ed.gov/fastfacts/display.asp?id=77

Olson, L., (2013). 4 Degrees That Guarantee a Job Offer, US News and World Report, Feb 28. Retrieved June 13, 2016 from http://money.usnews.com/money/blogs/outside-voices-careers/2013/02/28/4-degrees-that-guarantee-a-job-offer

Payscale, (2016). Payscale College Salary Report 2015-2016, Majors That Pay You Back. Retrieved June 13, 2016 from http://www.payscale.com/college-salary-report/majors-that-pay-you-back/bachelors and from http://www.payscale.com/college-salary-report/majors-that-pay-you-back/masters and from http://www.payscale.com/college-salary-report/majors-that-pay-you-back/mba

Pew Research, (2011). “Is College Worth It?” Retrieved from http://www.pewsocialtrends.org/2011/05/15/is-college-worth-it/ Schwartz, N., (2016). Wages Rise as U.S. Unemployment Rate Falls Below 5\%, New York Times, Feb 5, 2016

Singal, V., (2013). "Six Reasons Why Studying Computer Science Is Worth It", September 8. Retrieved on February 2, 2015 from http://www.huffingtonpost.com/vinamrata-singal/six-reasons-to-study-computer-science_b_3714030.html

Snyder, B., (2014). Top Tech Salaries Go to Those Who Graduate College, Infoworld, Oct 30, 2014, retrieved Jun 13, 2016 from http://www.infoworld.com/article/2840772/it-jobs/top-tech-salaries-college-graduates.html

StudentsReview ${ }^{\mathrm{TM}}$, (2015). Retrieved on March 8, 2015 from http://www.studentsreview.com/unemployment_by_major.php3

Uhlig, R., and Mehta, K., (2016). "Computer Science Graduates: Teaching Innovations, Earnings, and Reducing the Shortfall”, Journal of Research in Innovative Teaching, Vol. 9, Issue 1, p. 91-107, March.

Uhlig, R., Mehta, K., Silverstone, S., and Mossavar-Rahmani, F., (2015). "The Value of Business Education: A Case Study of Business Administration Graduates of a Large University”, Journal of Business and Behavioral Sciences, Vol. 7, Issue 1, p. 89-106, Spring.

US Bureau of Labor Statistics, (2013a). Economic News Release, Employment Status of the Civilian Population 25 Years and Over by Educational Attainment retrieved from http://www.bls.gov/news.release/empsit.t04.htm.

US Bureau of Labor Statistics, (2013b). Occupational Employment Statistics, May 2013 National Educational Employment and Wage Estimates. Retrieved from http://www.bls.gov/OES/current/oes_nat.htm\#15-0000

USDE, (2014). U.S. Department of Education, National Center for Education Statistics, The Condition of Education 2014 (NCES 2014-083), Annual Earnings of Young Adults. Retrieved on Jan 30, 2015 from http://nces.ed.gov/fastfacts/display.asp?id=77

US News and World Report, (2015). “Top 100 Jobs of 2015.” Retrieved on March 8, 2015 from http://money.usnews.com/careers/best-jobs/rankings/the-100-best-jobs 